Journal of Sustainable Development of Transport and Logistics

journal home page: https://jsdtl.sciview.net

Lau, Y.-y., \& Malchow, U. (2019). Revising Hong Kong's midstream operation: A discussion on the Port Feeder Barge concept. Journal of Sustainable Development of Transport and Logistics, 4(2), 6-21. doi:10.14254/jsdtl.2019.4-2.1.

\title{
Revising Hong Kong's midstream operation: A discussion on the Port Feeder Barge concept
}

\section{Yui-yip Lau *(D), Ulrich Malchow **(D)}

${ }^{*}$ Division of Business and Hospitality Management, College of Professional and Continuing Education,

The Hong Kong Polytechnic University,

Kowloon, Hong Kong

European Centre for Social Responsibility,

Constanta, Romania

yuiyip.lau@cpce-polyu.edu.hk

${ }^{* *}$ ISM International School of Management,

Brooktorkai 22, 20457 Hamburg, Germany

ulrich.malchow@ism.de / malchow@portfeederbarge.de

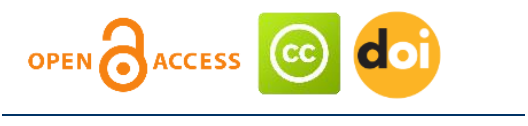

Article history:

Received: June 19, 2019

1st Revision: July 22, 2019

Accepted: September 09, 2019

\section{DOI:}

10.14254/jsdtl.2019.4-2.1

\begin{abstract}
Midstream operation (MSO) has played an important role in Hong Kong's port business since the 1960s. MSO has been seriously neglected in maritime transport research in the past. In the course of filling this significant research gap, we aim to address how a new type of harbor vessel - Port Feeder Barge (PFB) can strengthen the sustainability and attractiveness of MSO in Hong Kong and of the port in general. By introducing such type of vessel MSO becomes much safer and faster, much more efficient with less manpower being needed, provides higher flexibility and causes less environmental impact compared to the traditional Hong Kong midstream barges (HK barges). Due to its special layout as a deck carrier the PFB is also very well suited to be optionally fuelled with Liquefied Natural Gas (LNG) which would result into an ultimate "green" harbor vessel. Semi-structured, in-depth interviews with a number of maritime professionals involved in MSO activities in Hong Kong have revealed how PFBs could be employed in MSO, the potential regulatory issues and operating challenges and the critical success factors for further PFB deployment in the AsiaPacific region. The study provides insights how the PFB could provide notable advantages for a sustainable recovery of MSO in Hong Kong.
\end{abstract}

Keywords: midstream operation, floating crane, floating terminal, intermodal harbour vessel, intra-port haulage, container barge, LNG. 


\section{Introduction}

Hong Kong has been recognized as one of the most dynamic container ports in the world over the last few decades whereas midstream operation (MSO) has always played a vital role as an economic and effective alternative to land based container terminals. MSO has also released some capacity pressure from handling operations during peak hours (Shippers Today, 1999). Hong Kong's MSO is virtually a worldwide unique way of loading/discharging containers from seagoing vessels. Contrary to a ship which is berthed at a terminal MSO can be performed at anchorage simultaneously on both sides of the ship (Lau \& Ng, 2017). Since the 1960s, MSO has played a significant role in Hong Kong's port development and met thereby various customer needs (Fu et al., 2010). MSO is even regarded as a "must" in enhancing a substantial growth of Hong Kong's maritime industry and reinforcing Hong Kong's position as a global entrepôt (Lau \& Ng, 2017). Long before the existence of any container terminal all kind of cargo was loaded and discharged from ocean-going vessels at anchorage in Hong Kong waters by means of the typical Hong Kong midstream barges (HK barges). Since the early 1970s also containers have been handled by MSO whereas the used type of barge has hardly changed. HK barges are serving container vessels up to approximately 3,500 TEU size while being only equipped with a single and simple derrick as cargo gear having a capacity of around 50 TEU (Figures 1 and 2). Besides handling containers the typical HK barge is also used for waterborne construction work. Approx. 250 of these vessels are in service in Hong Kong waters being not selfpropelled but depend on towing tugboats.

In the course of the last decade Hong Kong's container terminals have significantly lost volume as they are suffering from stiff competition from neighboring ports in mainland China (e.g., Shenzhen, Guangzhou, Shanghai, Ningbo-Zhoushan and Qingdao) which are much cheaper not only for the seagoing vessels but also for the on-carriage of the containers (UNCTAD, 2018). Since the financial crisis in 2009, the total throughput has never exceeded the level before the drop. In 2016, the throughput has fallen again to the level of the crisis in 2009. This is of course also affecting MSO. Nevertheless, its volume has been constantly kept slightly above 1 million TEU.

Hong Kong is intensively seeking for ways to stop the ongoing container drain to its nearby ports in Southern China, notably Shenzhen port (Zhang et al., 2005). Introducing an advanced but still competitive state-of-the-art MSO could make this mode of container handling an attractive alternative to the expensive Kwai Tsing container terminals and therefore could stop losses of container throughput in Hong Kong. In the past, the midstream operators have gradually improved their service by investing in computerization, refurbishment of facilities, extension of service hours, staff education and training and hiring additional workforce to increase the service standards. As a result, the midstream industry could benefit from an improved operational flow, raised yard safety and a decrease of tractor waiting time. However, the business environment for midstream operators has remained difficult in the last few decades (Shippers Today, 1999).

The reason for the introduction of MSO as an alternative to cargo handling at the quayside was the high price of real estate in Hong Kong since ever which makes quay based cargo operation very expensive. This is even more the case with area intensive container handling. Hence, MSO has not disappeared with the introduction of containers although the cargo gear of the HK barges is anything else but well suited for the handling of containers. Cargo handling fees of MSO are $40 \%$ to $60 \%$ less than those charged by the land based terminals. MSO has experienced a sharp rise in the early 1990s when the trade volume within Southeast Asia has risen at rapid rates (Lau and Ng, 2017). More than $30 \%$ of the containers were handled midstream while Hong Kong had grown to the largest container port in the world at that time. Since that peak level MSO has generally lost market share. In absolute terms an all-time peak of 4.2 million TEU was reached in 2004 while its share felt to less than $20 \%$. Since that year MSO have been in decline, with the construction of Terminal 8 and Terminal 9 at the Kwai Tsing container terminals taking the number of berths from 14 to 24.For the last years MSO has stayed only for slightly more than $5 \%$ of the containers passing through Hong Kong (Figure 3). 
Figure 1: Traditional midstream operation in Hong Kong

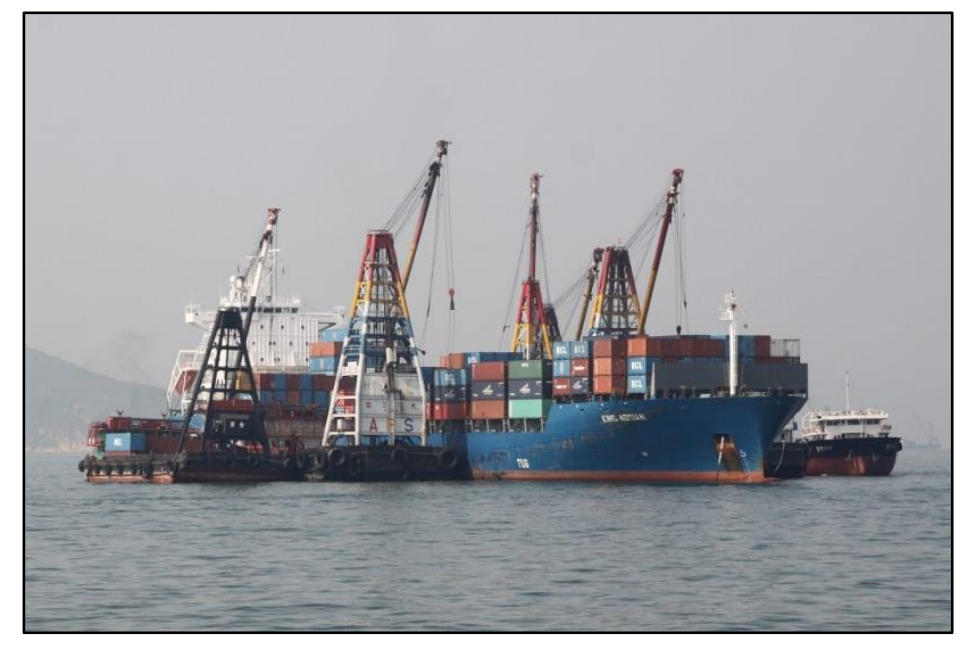

Source: author

Figure 2: Traditional midstream wharf in Hong Kong

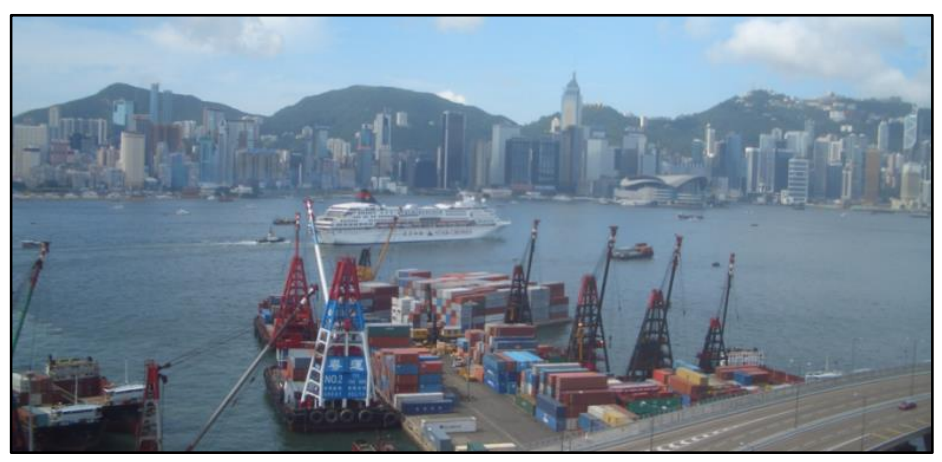

Source: author

Figure 3: Hong Kong container throughput

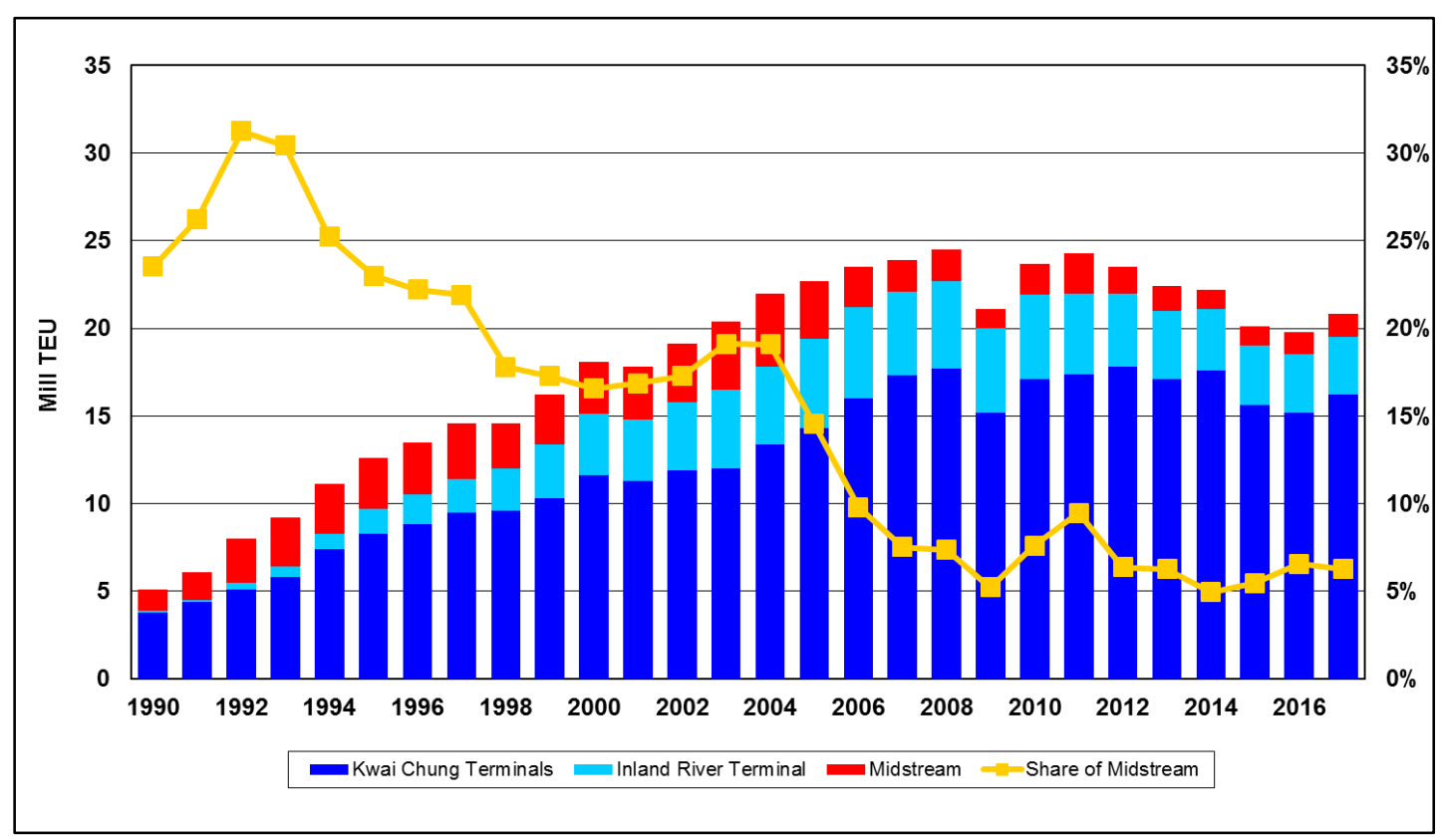

Source: Hong Kong Marine Department, 2018 
MSO is now facing an adversely impact from external marketing forces and operational inefficiencies. Nevertheless MSO is an iconic actor in the local maritime industry. In order to encounter with such critical situation the new Port Feeder Barge (PFB) concept has been developed. It can transform MSO from a low end to a high end service.

In the long term the PFB can be considered as a green logistics innovation for the entire Greater Bay Area (GBA) as it can mitigate the efforts for its internal container operation. The PFB provides a smart alternative to container trucking transferring intra-port container haulage from road to waterway. Hence the PFB definitely fosters the growth of sustainable development within the local maritime industry. The PFB can contribute to some resilience measures towards the negative impacts of cargo operations with regard to climate change circumstances. While the PFB has been developed in Europe the concept has yet not reached the full attention of researchers, industrial practitioners and policymakers in the Asian region. Their knowledge about the possibilities of the PFB in MSO still needs to be developed.

It must be realized that MSO has been seriously overlooked in maritime transport research in the past (Lau et al., 2017). In the course of filling this significant research gap, we aim to highlight how the PFB concept can strengthen the attractiveness and sustainability of MSO in Hong Kong. Therefore, we discuss at first the rationale behind the diminishing role of MSO within Hong Kong's maritime industry. Subsequently the paper is divided as follows: Section 2 explores the evolution of Hong Kong's port and the resulting challenges to MSO. Section 3 describes the concept of the PFB. Section 4 contains the results from the interviews with stakeholders from the local maritime industry regarding MSO. Finally, we examine in Section 5 how the PFB can contribute to the attractiveness and sustainability of MSO and how to turn the green port concept in Hong Kong into reality.

\section{Literature review}

\subsection{Evolution of Hong Kong port}

Hong Kong port has a long history and has evolved to one of the largest ports on the globe. Already during the Ming dynasty the Zheng He Navigation Chart included the island of Hong Kong in its drawing as Fat Tong Mun (i.e. the strait between Tung Lung Chau and the Clear Water Bay Peninsula). The momentousness of these outlying islands gave the seafarers a reference and transit point for navigation.

After signing the Treaty of Nanjing in August 1842 Hong Kong was officially under British colonial control. The intended development of the entrepôt and seaborne trade was first indicated in 1844. The coolie trade contributed to the growth of shipping to and from Hong Kong. From 1860 onwards the rise of Chinese merchants in Hong Kong (e.g. Yuen Fat Hong, Kin Tye Lung, and Wo Hing Hong) has contributed to the growth of the regional trade with neighboring cities like Macao and Guangzhou and has led to the establishment of an entrepôt. Since 1899, the position of Hong Kong port has evolved from an entrepôt into an international harbor which has gone along with the growth in international cargo trade and the development of regional and international passenger transport. In order to foster industrialization and modernization the British government had upgraded the port facilities by means of navigational aids, typhoon shelters, dockyards, terminals, piers, land reclamation and fairways between 1948 and 1966.

In the early 1960s, Hong Kong stepped into container handling. Before container terminals were constructed, the new standardized boxes were only handled at three facilities: the Kowloon Wharves of Hong Kong \& Kowloon Wharf \& Godown Co. Ltd., the North Point Wharves, and the Kowloon Docks. The main problems at that days were the insufficient handling equipment ashore and on board the vessels (Wang, 1998; Marine Department, 2018).

Encouraged by the progressing containerisation of international seaborne trade the British government took all measures in harbor planning and construction to develop the port of Hong Kong into a sophisticated container port which kept pace with the development of the local and international container trade. In the early 1970s, the British government laid the foundation for Modern Terminals Limited (MTL) and Container Terminal No. 1 while Kowloon Container Warehouse and Sea-Land Orient got Container Terminals No. 2 and 3 respectively. Hong Kong International Terminals (HIT) commenced operation at Container Terminal No. 4. In practice, Hong Kong container 
terminals are now under an unique operating scheme: The government provides infrastructural support and public services at its own expenses while the terminals are reclaimed, equipped and operated at the expense of the private developer. For Container Terminals No. 1 to 6 , the rights to generate the terminals were granted by private treaties. However, the operator of Container Terminals No. 7 and 8 has been appointed by a tender process. In addition, the ownership of the container terminals are allowed to be changed through buying, selling and exchanging of berths. Currently, HIT and MTL are the key operators at the Kwai Tsing Container Terminals. The remaining are Asia Container Terminals Ltd (ACT), COSCO and DP World (Airriess, 2001; Lau \& Ng, 2017; Marine Department, 2018).

Following the introduction of Deng Xiaoping's open door policy the Chinese coastal cities were moderately opened. Since Mainland China provides a vast hinterland for Hong Kong, the open door policy created a notable growth in traffic and trade volume as Southern China has experienced a dramatic economic growth. Hence a closer economic association with Hong Kong was created boosting the trade between Hong Kong and Mainland China (Zhang et al., 2005; Marine Department, 2018). Supported by favorable trade policies Hong Kong has transformed into the world's busiest container port. Hong Kong container terminals have recorded 0.726 million TEU in 1974 and reached 4.464 million TEU in 1989 (Marine Department, 2018). In the following the total container throughput of Hong Kong developed from 9.2 million TEU in 1993 to over 19.1 million TEU in 2002 (Yeung et al., 2004). Responding to the increasing demand for container handling, expanding the terminal capacity was a "must" in the following years. Container Terminal No. 9 which is located at the southeastern shoreline of Tsing Yi Island was introduced in July 2004. The enlargement of the Kwai Tsing container terminals was intended to help Hong Kong to further keep its role as one of the leading ports for Southern China in the $21^{\text {st }}$ century (Marine Department, 2018).

\subsection{Roles and challenges of MSO in Hong Kong}

MSO is a method to load and unload containers on/from ocean going ships at anchorage in the harbor at lower fees. In general midstream operators serve various kinds of vessels, ranging from semi to fully cellular container ships, break-bulk carriers and bulkers. Because of its lower fees MSO is able to attract small and medium-sized vessels of regional trades which cannot afford the high fees at the terminals. Contrary to container terminals, MSO allows for the loading and unloading of containers on both sides of the vessel. In the 1980s and early 1990s MSO contributed with a significant portion to the total throughput of Hong Kong, e.g. with more than 30\% in 1992. In order to keep its competitiveness, the equipment has been constantly upgraded and cargo operation has been adjusted to the needs of the ever developing container system.

The main MSO operators are Hoi Kong, China Merchant and Floata. Other MSO operators still provide MSO service but inactive MSO business including Tai Wah Sea/Land Heavy Transportation Ltd, Fat Kee Stevedores Ltd, K-Power Marine Group Co., Ltd, Yuen Fat, Pacific Century, Luen Tong and Star Shipping (Marine Department, 2018). Only 40-50 barges have remained in the MSO market. In the past 10 years no new traditional HK barge has been built as no growing business is expected in the forthcoming years. The new building prices are estimated at HKD 13 to 15 million. From the operator's perspective this is considered as being not feasible any more for the operation of MSO.

The HK barges deployed in MSO require shore based berthing spaces to load and unload the containers and other cargoes to be taken to and from the ocean going vessels. Accordingly Public Cargo Working Areas (PCWAs) have been established to meet the demand. Currently there are six PCWAs (i.e., New Yau Ma Tei, Rambler Channel, Stonecutters Island, Tuen Mun, Western District and Chai Wan) and two public waterfronts of 4,936 m supporting MSO.

In order to improve yard safety and operational efficiency the MSO operators have made some efforts with regard to the improvement of their facilities, additional workforce, computerization, staff training and extension of service hours (Shippers Today, 1999). MSO operators are under continuous pressure in their rivalry with the container terminals and also the River Trade Terminal (RTT) to reduce their tariffs.

With regard to the future the HKSAR government has seriously overlooked the sustainability and potential of the MSO. According to Lau and Ng (2017), MSO had to face remarkable changes in its operational environment including: (1) PCWAs nearby the Central Business District (CBD) were 
reallocated and recalled for other objectives; (2) The original allocation of PCWAs was carried out under short-term tenancy from the government. After 2008, the allocation of PCWAs has operated under an open auction process that has risen the overhead costs of MSO; (3) Numerous accidents have forced the government to take proactive measures to increase the safety of MSO; (4) Safety concerns have limited the maximum number of containers that may be loaded onto a barge. Consequently, MSO is presently recognized as the least efficient and most dangerous method of cargo handling with a questionable economic benefit. While various PCWAs are occupying high value waterfront sites with high development potential it is proposed that some existing PCWAs are to be vacated before 2020 (HKSAR LEGCO, 2004).

The traditional HK barges are equipped with their own cargo gear, but the handling method is far from being sophisticated. The A-frame derricks have a single beam which is just controlled by wires and is not even fitted with a spreader, but instead rely only on steel wires being fitted manually to the corner castings of the containers. This is why traditional MSO work is often hazardous as it involves stevedores working on top of the handled containers (Figure 4 a). In fact, this is cargo handling technology from the last century and complies hardly with international safety standards. In average 4 fatal accidents are reported each year in connection with MSO! Hence, such operation is not allowed in Europe, North America and most other ports in the world. Apart from Hong Kong a few midstream barges are also said to operate in Vietnam and Angola. Apart from the health and safety issues related to the traditional HK barges, they are not self-propelled (not even pushed but towed). Hence enhancing the sustainability of MSO is an urgent need for the maritime industry of Hong Kong anyhow.

Figures 4 a \& b: Midstream operation \& twin lift tower spreader
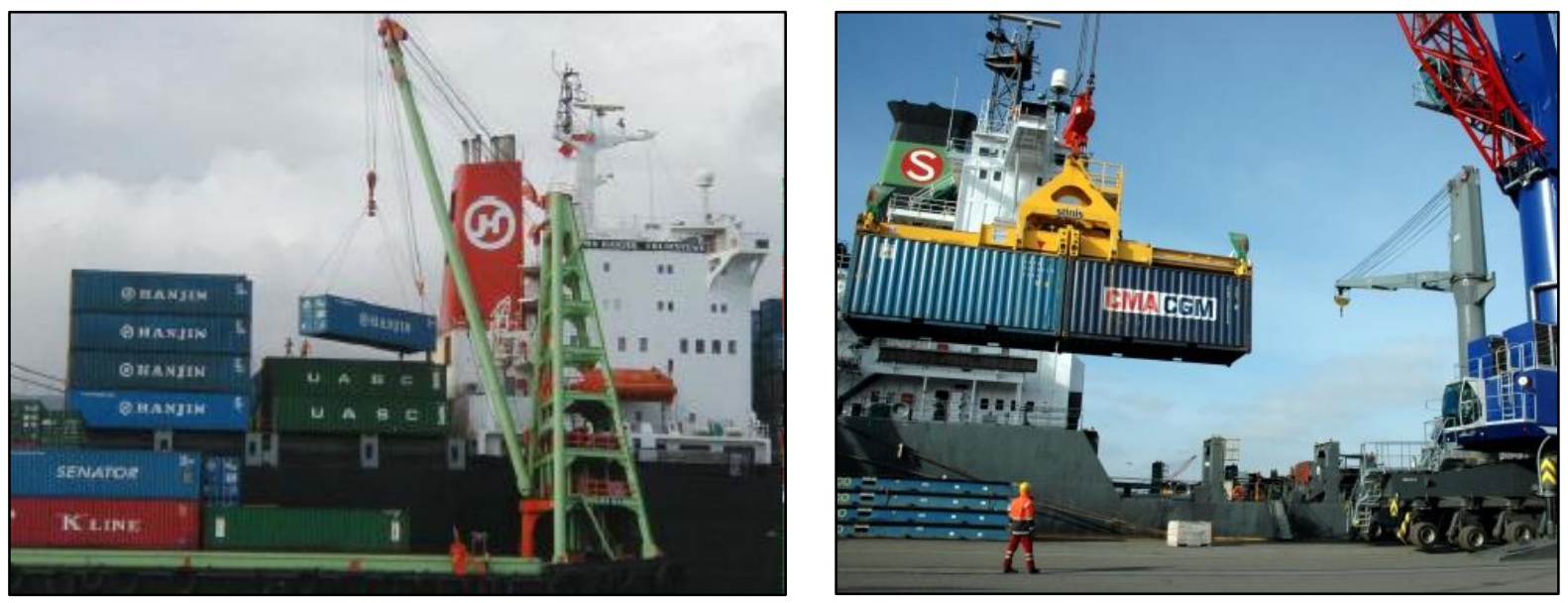

Source: author

The introduction of the PFB in MSO concept would allow for more safety, handling speed, efficiency, flexibility and environmental protection. Furthermore bigger vessels can be served with the PFB concept.

\section{The Port Feeder Barge concept}

The internationally patented PFB design comprises of a self-propelled container pontoon with a capacity of 168 TEU (completely stowed on the weather deck), equipped with its own state-of-the-art heavy-duty container crane mounted on a high column (Figure 5). The crane is equipped with an automatic spreader, extendable from $20 \mathrm{ft}$ to $45 \mathrm{ft}$, including a turning device. A telescopic over height frame to handle oversized flats is also carried on board. The barge is of double-ended configuration, intended to make it extremely flexible in connection with the sideward mounted crane. Due to the wide beam of the vessel no operational restrictions (stability) for the crane shall occur. The vessel is equipped with 2 electrically driven rudder propellers at each end in order to achieve excellent maneuverability and the same speed in both directions. Hence the vessel can easily turn on the spot and can even navigate sidewards. While half of the containers are secured by cell guides, the other half 
is not, enabling the vessel to carry also containers in excess of $40 \mathrm{ft}$ as well as any over-dimensional boxes or break bulk cargo. 14 reefer plugs allow for the overnight stowage of electrically driven temperature controlled boxes.

The key element of the worldwide unique (and therefore patented) PFB concept is its own full scale heavy duty container crane. While it looks like a standard shipboard crane, all its mechanical components have been especially designed for continuous operation - unlike standard shipboard cranes, which are designed for operation only every few weeks when the vessel is in port. The crane has a capacity of 40 tons under the spreader, at an outreach of 27 meters (maximum outreach: $29 \mathrm{~m}$ ).

When berthed, the PFB is able, without being shifted along the quay, to load or discharge 84 TEU in three layers between the rails of a typical quayside gantry crane (Figure 6, b). This is more than sufficient with a total loading capacity of 168 TEU. That is why the full outreach of the crane is not always needed. Berthing the vessel with the crane on the opposite side of the quay (Figure 6 a) would speed up the crane operation as the turning time of the outrigger is reduced. The height of the crane column is sufficient to serve even high quays in open tidewater ports at low tide while stacking the containers in several layers. Due to its short length of 64 meters the PFB needs only a small gap between two deep sea vessels at the terminals for self-sustained operation.

\section{Figure 5: Port Feeder Barge (computer rendering)}

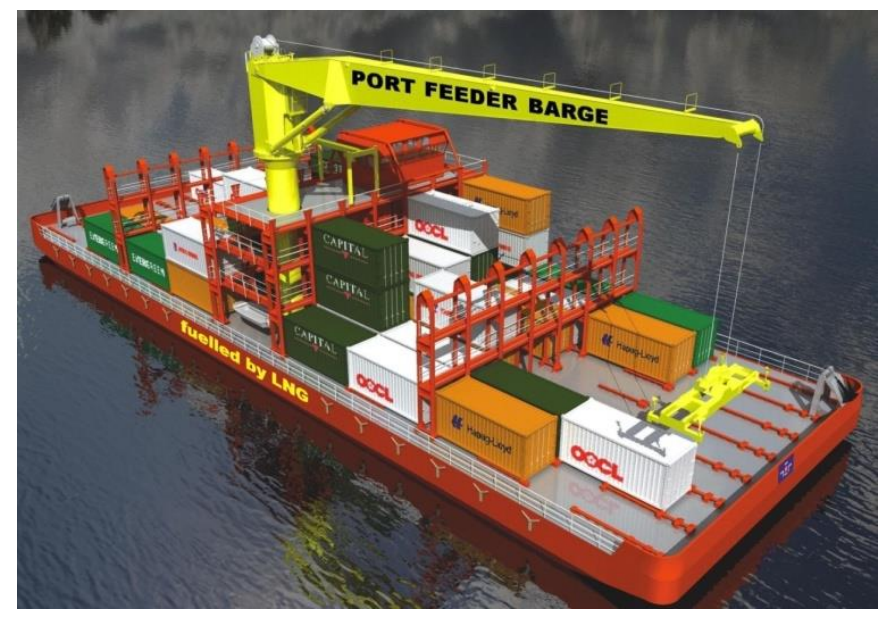

Source: PORT FEEDER BARGE, Hamburg

Type:

Length o.a.:

Beam o.a.:

Height to main deck:

Max. draft (as harbor vessel):

Deadweight (as harbor vessel):

Gross tonnage:

Power generation:

Propulsion:

Speed:

Class:

Capacity:

Crane:

Spreader:

Accommodation:

\section{Main Data}

self-propelled, self-sustained, double-ended container barge

$63.90 \mathrm{~m}$

$21.20 \mathrm{~m}$

$4.80 \mathrm{~m}$

$3.10 \mathrm{~m}$

$2,500 \mathrm{t}$

approx. 2,000 GT

diesel-/gas-electric

$2 \times 2$ electrical rudder propeller of $4 \times 280 \mathrm{~kW}$

7 knots at $3.1 \mathrm{~m}$ draft

+ GL 100 A5 K20 Barge

equipped for the carriage of containers, Solas II-2, Rule 19

+ MC Aut

168 TEU (thereof $50 \%$ in cell guides), 14 reefer plugs

LIEBHERR CBW 49(39)/27(29) Litronic (49 t at $27 \mathrm{~m}$ outreach) automatic, telescopic, 6 flippers, turning device, over height frame 6 persons (in single cabins) 
The vessel shall fulfil the highest environmental standards. A diesel- or gas-electric engine plant with very low emissions supplies the power either for propulsion or crane operation. The vessel can be operated by a minimum crew of 3 whereas in accordance with the relevant manning requirements in total up to 6 persons can be accommodated in single cabins.

The operation of the PFB is not limited to inside sea ports. As the hull shall be classified according to the class notification for seagoing vessels the operation in (sheltered) open waters off the coast is also possible which opens some further interesting opportunities for MSO not only in Hong Kong.

The detailed design of the vessel has been developed in close cooperation between Messrs. PORT FEEDER BARGE and TECHNOLOG both of Hamburg/Germany.

It is assumed that the typical Hong Kong style MSO could very much benefit from deploying PFBs as they could be used to significantly improve safety and productivity.

\subsection{Productivity}

Figures 6 a \& b: Port Feeder Barge: Outreach of crane and turning circle

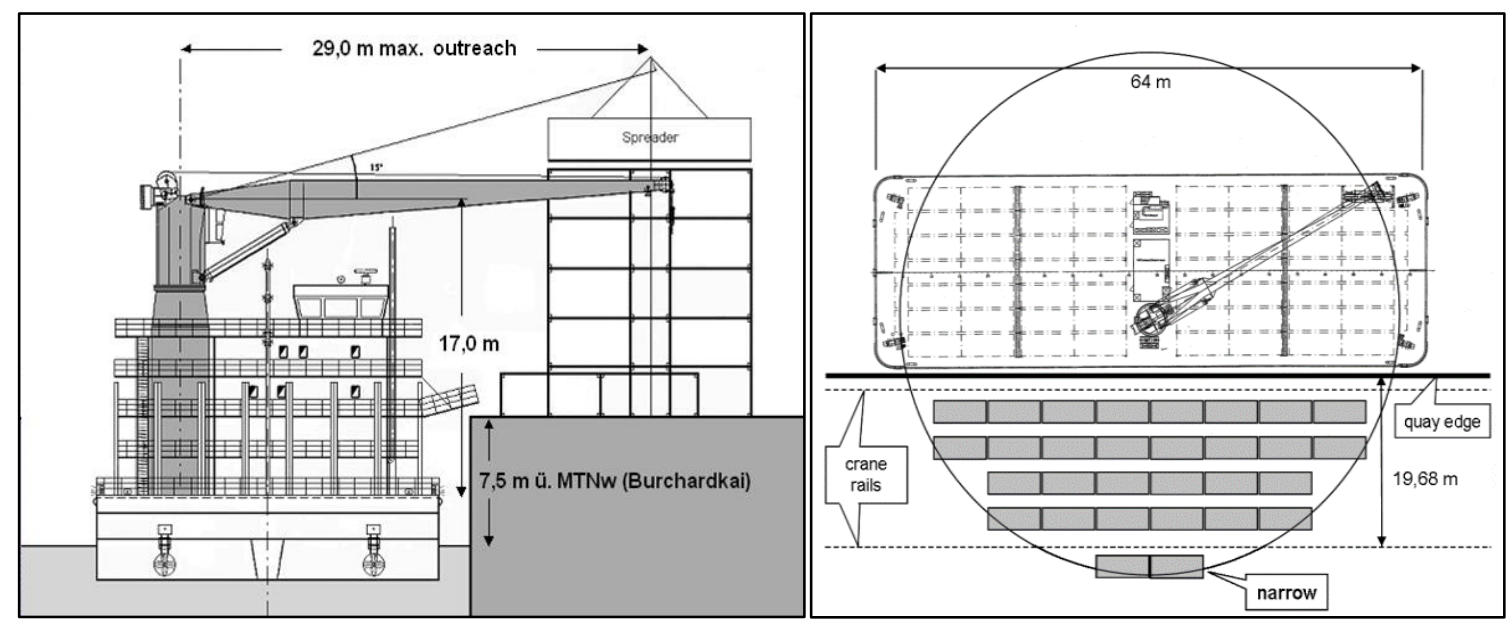

Source: PORT FEEDER BARGE, Hamburg

When systematically comparing traditional HK barges (Figure 1) and the PFB concept (Figure 5) for MSO regarding safety and productivity the load cycles (4 phases) have to be investigated in detail (Table 1):

\section{Picking up of container (either from the seagoing vessel or from the barge)}

Lowering/positioning of lifting attachment:

The PFB takes advantage from the fully automatic and telescopic spreader avoiding any person to be placed on top of the containers. The spreader is equipped with a turning device, an automatic gravity point adjustment and 6 individually controlled flippers which guide the spreader into the right position on top of the container. With the sensitive crane control in combination with its turning device the spreader can be carefully positioned on top of the containers. Meanwhile even twin lift capability is available for tower type spreaders (e.g. for mobile harbor cranes, Figure 4 b).

Locking:

Once the spreader is positioned on top of the container the locking of its 4 pins into the corner castings is just a matter of pushing a button by the crane driver in his cabin. HK barges do operate without spreaders. Instead 4 loose wire ropes with hooks at their ends have to be fastened manually to the corner castings (Figure $4 \mathrm{a}$ ). For that purpose persons have to work on top of the container and have to leave it quickly (either to adjacent containers or stepping down via ladders) before it is lifted. The persons have to watch very carefully for not being hit by one of the swinging hooks especially when the vessel is rolling.

- Hoisting:

In addition to all the labor accidents a lot of damage to the containers and also to the seagoing vessels is reported from the rough method of traditional MSO. The fact that there is no motion control 
around the vertical axle of the handled container contributes very much to all of the experienced damages. Hence, collisions with adjacent containers are unavoidable with HK barges while hoisting the container. Instead the spreader operation of the PFB with its integrated turning device and its sensitive crane control allows for controlled hoisting minimising any bumps to neighboring boxes.

\section{Slewing beam with load}

The slewing of the simple beam of HK barges is controlled by two wire ropes (like old style cargo gear). One rope has to be tightened and the other one has to be eased simultaneously. Unavoidably the ropes are chafing frequently along the containers stowed on deck.

By nature of its cargo gear the operational area of the beam of the HK barges is limited to less than $90^{\circ}$ to each side whereas the crane of the PFB can turn $360^{\circ}$ (Figure 7). Hence HK barges require also more time consuming interruptions of the cargo operation for shifting the barge alongside the seagoing vessel to reach all required container positions. As a $\mathrm{HK}$ barge reaches only one third of the containers on the seagoing vessel compared to the PFB (without being shifted) alone the time for shifting will be more than triple (see below).

\section{Dropping off container}

Positioning of container:

With the sensitive crane control in combination with the turning device of the PFB it is much easier to exactly reach the final stowage position of the container compared to the old fashioned and rough cargo gear of the HK barges - especially when the vessels are rolling. When lowering the container to its final stowage position the turning device of the PFB becomes the decisive tool to avoid bumping against other containers.

- Unlocking:

Again, it needs only a touch of a button in the crane driver's cabin to unlock the container from its lifting attachment when operating a PFB. With a HK barge persons have to climb on to the top of the container to unfasten the 4 wire ropes. This is not only time consuming but very dangerous as the statistic of labor accidents in Hong Kong harbor shows.

\section{Empty hoisting:}

Only the hoisting of the 4 hanging down wire ropes appears to be easier than of an empty but bulky spreader. However the sensitive crane control and the turning device allows to avoid bumping against adjacent containers.

\section{Slewing beam without load $\rightarrow$ see 2 . (above)}

\section{Table 1: Load cycle analysis}

\begin{tabular}{|c|c|c|c|}
\hline & Phase & HK Barge & PFB \\
\hline \multirow{3}{*}{$\begin{array}{l}\text { Picking } \\
\text { up }\end{array}$} & $\begin{array}{l}\text { Lowering/positioning } \\
\text { of lifting attachment }\end{array}$ & Precise positioning not required & $\begin{array}{l}\text { Precise positioning of spreader by sensitive } \\
\text { crane control and turning device }\end{array}$ \\
\hline & Locking & 4 wire ropes to be fastened manually & Button touch \\
\hline & Hoisting of container & $\begin{array}{l}\text { No motion control } \\
\text { around vertical axle ! }\end{array}$ & $\begin{array}{l}\text { Sensitive crane control and turning device } \\
\text { to avoid collisions with other containers }\end{array}$ \\
\hline \multicolumn{2}{|c|}{ 2. Slewing beam with load } & Restricted area of operation & $360^{\circ}$ operation circle \\
\hline \multirow{3}{*}{$\begin{array}{l}\text { 3. Dropping } \\
\text { off }\end{array}$} & $\begin{array}{l}\text { Lowering/positioning } \\
\text { of container }\end{array}$ & $\begin{array}{l}\text { No motion control } \\
\text { around vertical axle ! }\end{array}$ & $\begin{array}{l}\text { Precise positioning of spreader by sensitive } \\
\text { crane control and turning device }\end{array}$ \\
\hline & Unlocking & 4 wire ropes to be untied manually & Button touch \\
\hline & Empty hoisting & Precise hoisting not required & $\begin{array}{l}\text { Sensitive crane control and turning device } \\
\text { to avoid collisions with other containers }\end{array}$ \\
\hline \multicolumn{2}{|c|}{ 4. Slewing beam without load } & Restricted area of operation & $360^{\circ}$ operation circle + \\
\hline \multicolumn{2}{|c|}{ Conclusion (evaluation points) } & ++ & ++++++++ \\
\hline
\end{tabular}

Source: Author 


\subsection{Rolling}

The operation of HK barges as well as of PFBs are both affected by rolling motions against the seagoing vessel which would slow down the operation, especially during the positioning process. As seaway induced motions are generally of regular type the crane drivers of both types of vessel can prepare for finding the right moment for the final slope of the container or the empty spreader.

However, the active usage of its turning device and the sensitive crane control of the PFB allows for much better and precise compensation of the rolling motions and prevents from damages.

To further cope with the rolling motions of the two vessels moored alongside each other the PFB concept allows for the installation of an additional so-called 'stabilising winch' which is offered by some crane manufacturers (e.g. Liebherr). Such device is mounted on the crane's beam (close to the column) to tighten a wire rope which is directly connected to the turning device (just above the spreader). Hence, the swinging motions of the spreader are significantly dampened.

\subsection{Accessibility}

A comparison has been made between the PFB and a typical HK barge regarding the slot accessibility while serving a typical 6,000 TEU vessel (on deck: 15 rows, 7 layers; in holds: 13 rows, 8 layers).

From a geometric analysis (Figure 7) it is obvious that the PFB benefits from the $360^{\circ}$ operational circle of its crane regarding the horizontal slot accessibility whereas a typical HK barge is limited to even less than $90^{\circ}$ to each side. Furthermore, even if both beams would be of the same length, the PFB takes advantage from a wider operational area due to its sidewards mounted crane (Figure 7 \& 8).

Due to the fact that the beam fulcrum of the PFB is by principle located at least 4 container layers higher compared to a HK barge a much better accessibility to many containers stowed on deck is achieved especially when containers have to be positioned behind other containers (Figure 8).

As HK barges are working without spreaders a lot of utilizable height of the hoisting rope is lost for the lifting attachment, especially when $40 \mathrm{ft}$ containers are handled (the angle of inclination of the wire ropes is recommended to be under $45^{\circ}$ ) whereas the height of the spreader (incl. its turning device) is much less (Figure 8).

The results of the horizontal and vertical accessibility have been summarized in terms of numbers of accessible containers with both types of barges (Figure 9): It is quite obvious that the PFB has access to roughly the triple number of containers than a typical HK barge (without being shifted alongside the deep sea vessel)! Furthermore, there is much more flexibility in stowage planning as even with 6,000 TEU vessels the first three layers on the hatch covers can be stowed without being forced to follow a certain loading/discharging order. This is not the case with typical HK barges.

Normally HK barges are restricted to moor alongside seagoing vessels only in the midship area where the hull is plane and vertical. Containers stowed at the vessel's bow or stern are difficult to load/discharge as the barge has to be positioned under the overhanging hull lines. Hence not all slots of seagoing vessels are accessible to HK barges. However, the self propelled PFB allows also for being moored at the bow and stern area of seagoing vessels: By using its rudder propellers the thrust can push the PFB away from the vessel while keeping the mooring lines tight. Due to the higher horizontal slot accessibility of the PFB and its superior mooring capability more slots on board of the seagoing vessel can be used for containers to be loaded or discharged in Hong Kong (higher stowage flexibility). 
Figure 7: Hong Kong midstream barge vs. Port Feeder Barge

- Horizontal Slot Accessibility (serving a 6,000 TEU vessel)

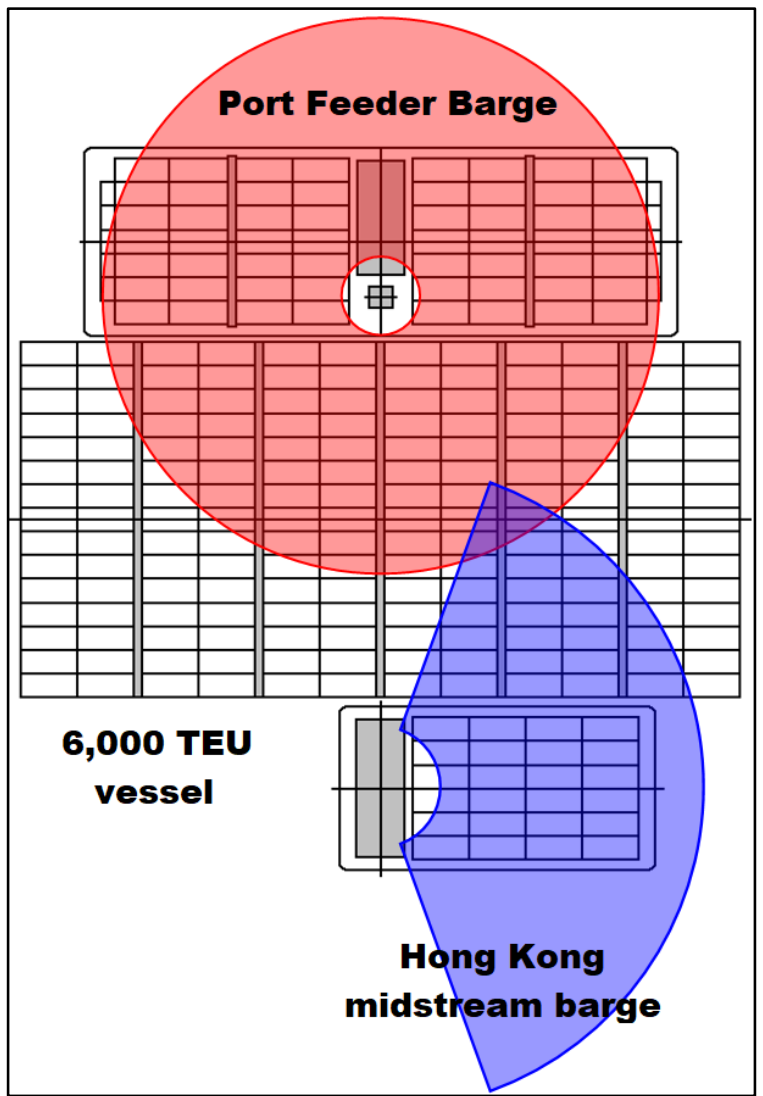

Figure 8: Hong Kong midstream barge vs. Port Feeder Barge - Vertical Slot Accessibility (serving a 6,000 TEU vessel)

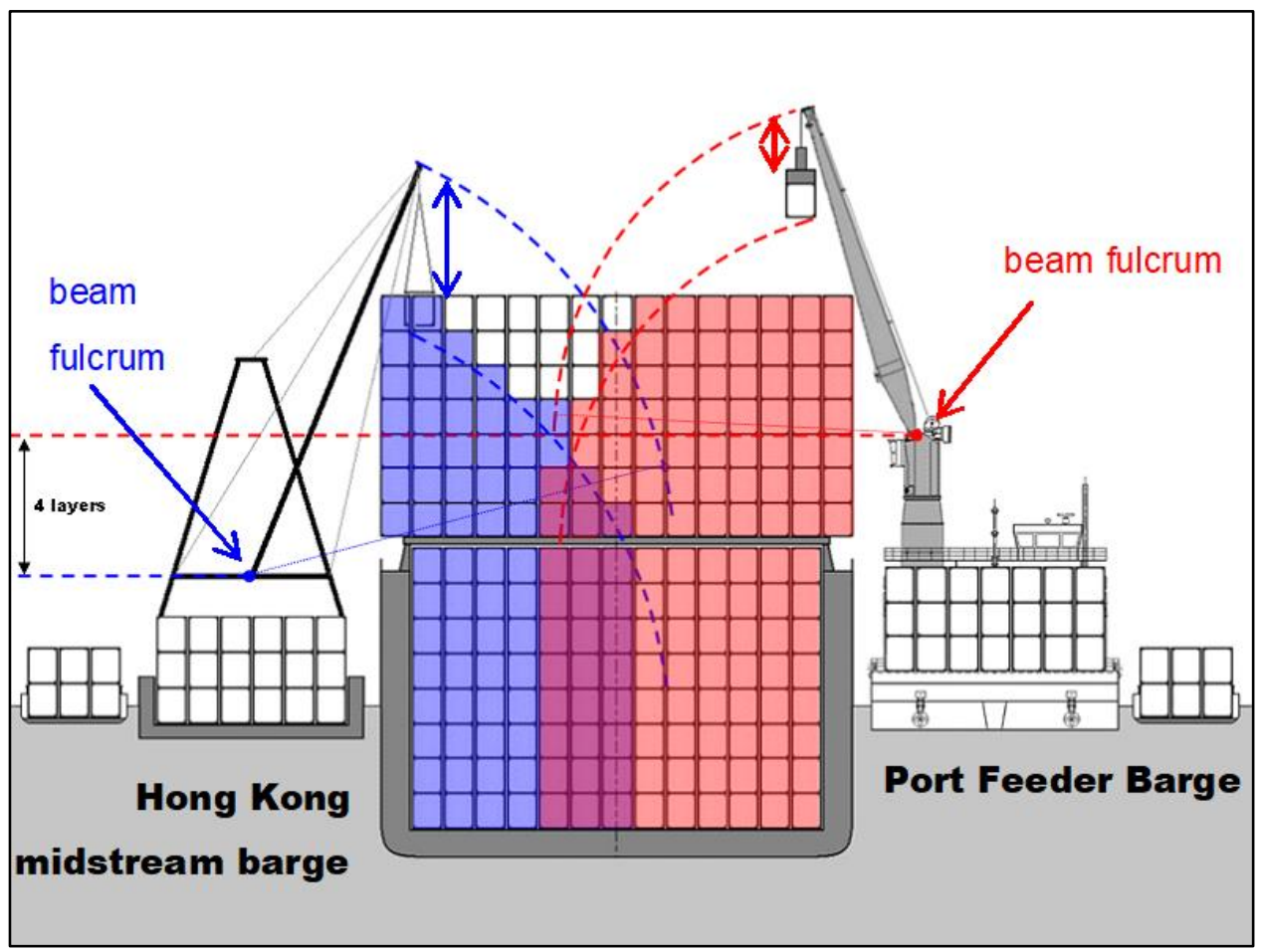


Figure 9: Hong Kong midstream barge vs. Port Feeder Barge - Total Slot Accessibility (serving a 6,000 TEU vessel)

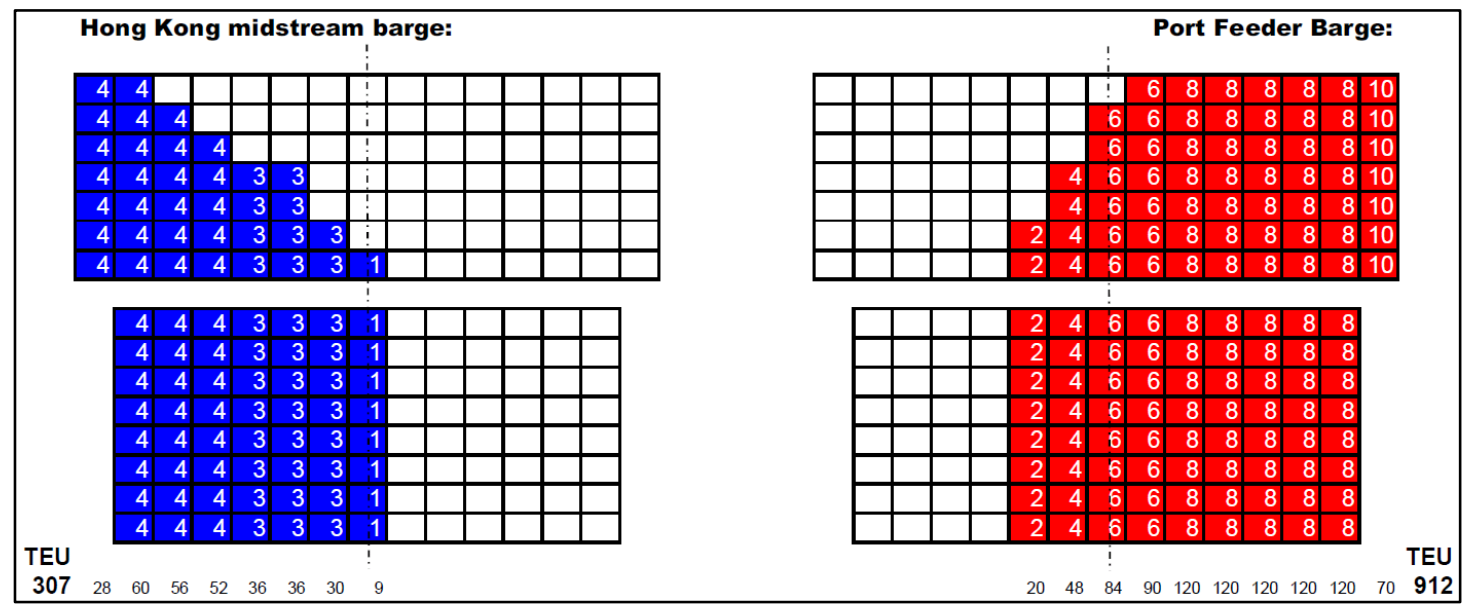

\subsection{Optionally fuelled with LNG}

All state-of-the-art but costly measures to be taken to keep the exhaust emissions of dieselelectric engine plants at an envisaged minimum (exhaust scrubbers, urea injection, filters etc.) can be avoided when choosing LNG as fuel (Figure 10). Due to the immense resources and its environmentally friendly combustion process LNG is said to be the maritime fuel of the future.

Figure 10: Effects on emissions when using LNG as fuel

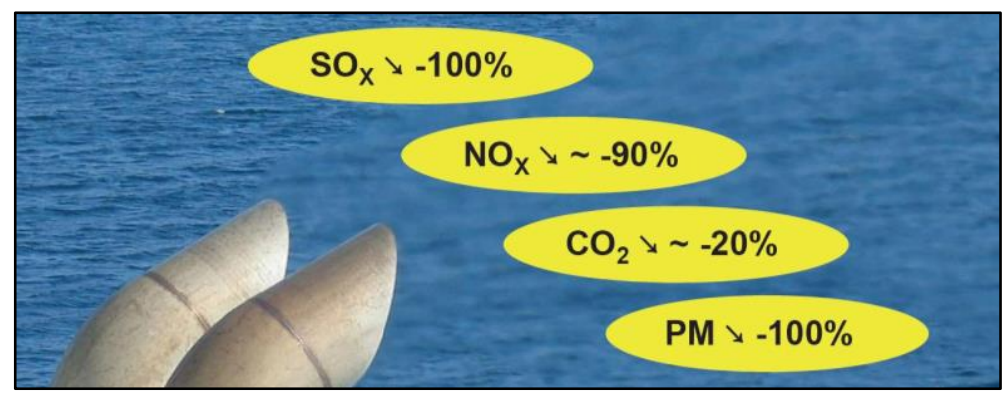

The PFB would be an ideal demonstrator for LNG as ship fuel:

- As a harbor vessel it does not rely on a comprehensive network of bunker stations. Only one facility was sufficient. The PFB - being a launching customer for this promising new maritime fuel - could at first even be supplied out of LNG tank trucks paving the ground from the demand side for a special LNG infrastructure to be introduced (solving the chicken-eggdilemma).

- As the PFB is of pontoon type there is plenty of void space below the weather deck. Hence the accommodation of the voluminous LNG tanks would not result in any loss of cargo space as it would be the case with many other types of (harbor) vessels (Figure 11). 
Figure 11: Possible accommodation of LNG tanks on board the Port Feeder Barge

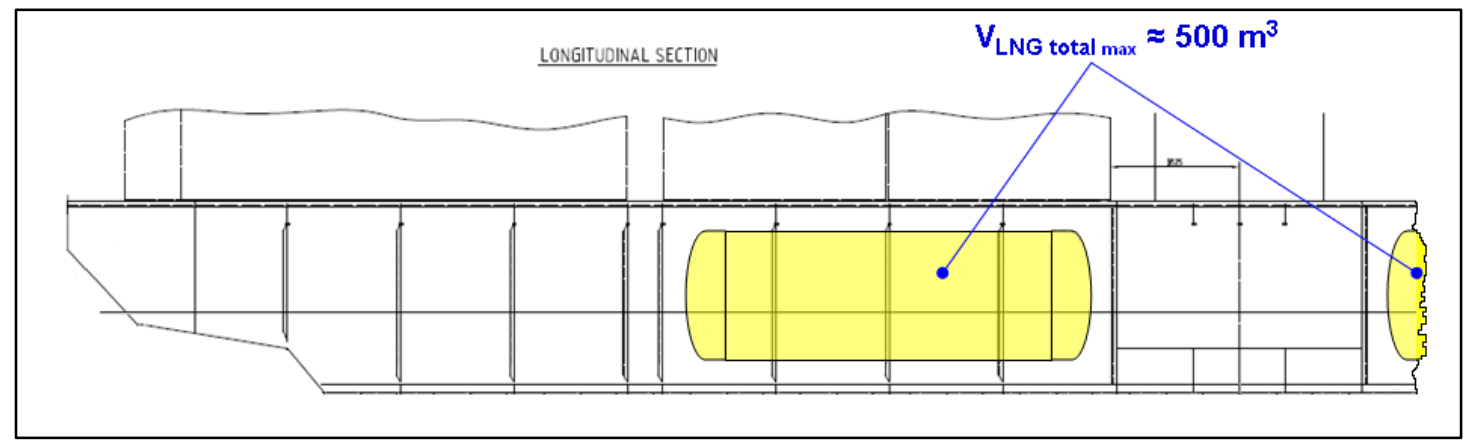

Source: PORT FEEDER BARGE, Hamburg

By using LNG as fuel the PFB concept could be considered not only as a smart but also as a 'green innovation' for advanced container logistics in Hong Kong able to comply with all emission control regulations from the Hong Kong Marine Department which might apply in the future.

\section{Interviews}

A qualitative research methodology has been employed to collect substantial unpublished information. In order to supplement the findings of the study, six face-to-face, semi-structured interviews with different stakeholders from the Hong Kong maritime industry have been conducted: consultant, ship agent, liner shipping company, terminal operator, logistics association and university. All interview partners hold supervisory and management positions with an average of 30 years working experience in the maritime industry of Hong Kong. The profiles of the interviewed persons are listed in Table 2. Due to granted confidentiality, all details of the interviews cannot be quoted. The interview questions are mainly focused on the potential role the PFB can play in Hong Kong's MSO; the comparative advantages of the PFB when employed in MSO; the relevant regulatory issues and operating challenges; the contribution the PFB can deliver to a green port concept and the critical factors for further PFB deployment in the Asian-Pacific region.

\begin{tabular}{|c|c|c|c|c|}
\hline & Position & Nature of Company & Department & $\begin{array}{c}\text { Working Years in } \\
\text { the Maritime } \\
\text { Industry }\end{array}$ \\
\hline 1 & Manager & Consultancy & $\begin{array}{l}\text { Maritime } \\
\text { Consultant }\end{array}$ & 45 \\
\hline 2 & Captain & Ship Agent & Operations & 44 \\
\hline 3 & General Manager & Liner Company & Operations & 36 \\
\hline 4 & $\begin{array}{c}\text { Head of Barge and Feeder } \\
\text { Strategies }\end{array}$ & Terminal Operator & Operations & 30 \\
\hline 5 & Executive Director & Logistics Association & NA & 40 \\
\hline 6 & Professor & University & $\begin{array}{c}\text { Logistics and } \\
\text { Maritime Studies }\end{array}$ & 40 \\
\hline
\end{tabular}

Mostly all interview partners have confirmed that MSO plays a diminishing role in Hong Kong due to a lack of financial incentives set by the government, large scale of land reclamation, missing human resources and public promotion. Also Lau and Ng (2017) indicated that MSO will encounter with unfavorable circumstances pertaining to unstable sea condition that influenced cargo handling, strong competitors, a decreased number of cargo barges, an insufficient waterfront, longer distances from the waterfront to the anchorage areas and increasing competition by direct international sailing to/from PRD ports. The interviewees' viewpoints align clearly with the literature. MSO not only faces internal weaknesses that leaves the business with a disadvantage compared to its competitors (e.g. container terminals and the River Trade Terminal), but is also facing with the threats of the external environment. If the HKSAR government remains passive regarding MSO, the ongoing decline of MSO is unavoidable. Hence the introduction of the PFB concept could ease the pressure on MSO. 
In general the different interviewees had different opinions on the possible application of the PFB concept in MSO. Some interview partners confirmed the advantages the PFB could provide to MSO in Hong Kong. Especially the representative from the shipping agency has emphasized that the PFB can significantly enhance the attractiveness and sustainability of MSO in Hong Kong. To a large extent the PFB would provide a service with modern equipment that is more reliable, and safe. The PFB would also provide an independent cargo hold area to avoid re-stowage costs and container damage. From the user's perspective the PFB design could save operational costs and increase safety for people, vessel and cargo.

Some interview partners doubted the economic viability of the PFB as it had to compete with much cheaper traditional HK barges. It was confirmed that lacking safety is a big issue which is costing some lifes each year. Consequently MSO operators have to bear the high marine insurance costs, manpower training costs and inspection costs. Because of the risky job nature it is difficult to attract young talents for the industry and adversely affect its public image. Thus the introduction of the PFB concept could fundamentally change the industrial routine of MSO.

Almost all interview partners have confirmed that the PFB could contribute to the reduction of emissions of MSO as it is fuelled by LNG. Under the green transport policy and the concept of a smart transport city, the introduction of the PFB in Hong Kong would be most favorable. However, some interview partners asked to bear in mind the lacking availability of LNG which had to be solved very urgently. Some issues like a suitable waterfront location for a LNG plant (incl. storage facilities) and the identification of LNG suppliers still need to be solved. These critical issues were still under discussion between the HKSAR government and the local maritime industry. It was further mentioned that also the PFB needs a sheltered berth for the typhoon season. This might be an obstacle for the future of PFB development in Hong Kong. In order to speed up the PFB implementation it was proposed that the HKSAR government could organize some workshops, seminars, forums to collaborate with different business stakeholders (e.g., MSO operators, Marine Department, policymakers, terminal operators, logistics associations, intermodal transport operators, third party logistics service providers, academics).

Based on the statements of the interviewee partners, a summary table has been created to compare between conventional MSO and PFB operation in different aspects (Table 3).

\section{Table 3: Comparison between HK barges and PFB}

\begin{tabular}{lcc}
\hline Aspect & HK barge & PFB \\
\hline Investment & +++ & + \\
Safety & --- & +++ \\
Operational Efficiency & -- & +++ \\
Size of vessel to be served & + & +++ \\
Flexibility & + & +++ \\
Overall Economy & + & + \\
Environmental Impact & + & +++ \\
\hline
\end{tabular}

Remarks: Advantageous refers to “+++"; Moderate refers to “+” and Poor refers to "---"

\section{Discussion and conclusion}

The detailed analysis of the motion sequences has revealed that the safety, flexibility and the productivity are expected to be much higher and the danger of damages to be much less with the PFB compared to the traditional MSO (Table 1). The productivity can be further increased by using a twin lift spreader which allows for $2 \times 20 \mathrm{ft}$ operation (Figure $4 \mathrm{~b}$ ).

Although the lowering and the hoisting of the empty lifting attachment appears to be easier with a HK barge (4 hanging down wire ropes vs. a bulky spreader) the more relevant lowering, hoisting and fastening/unfastening of the containers itself is definitely much easier, safer and faster with the PFB!

Furthermore it can be concluded that the PFB easily allows to serve even vessels of up to 6,000 TEU size midstream (by further heightening the crane column even bigger vessels could be served). Hence the PFB still allows also for MSO with seagoing vessels which are simply too big for the existing HK barges. 
Summarizing the comparison between the traditional HK barge and the PFB for MSO it can be concluded that the deployment of PFBs is expected to provide the following valuable advantages which could contribute to a recovered share in Hong Kong's container throughput:

- More safety (less labor fatal accidents, less damage to containers, cargo and vessels)

- Less interruptions

- More load cycles per hour

- Less barge shiftings along the seagoing vessel necessary

- More slots of the seagoing vessel are accessible for midstream operation

- Better stowage flexibility on the deep sea vessel and on the barge

- Possibility for twin lift operation

- Bigger vessels can be served midstream

- Less manpower necessary

- Independent from tug boats

- Best possible maneuverability (by 4 rudder propellers)

- More container stowage capacity on the barge

Besides MSO the PFB could be used in many other container ports to ...

- shift container trucking within sea ports to the waterway;

- ease feeder operation within multi terminal ports by consolidating feeder containers at one terminal;

- improve the intermodal connectivity of inland navigation within sea ports (acting as a floating terminal for inland barges and relieving the deep sea terminals from inefficiently serving then numerous small vessels by their huge gantry cranes.

It can be concluded that the PFB could provide notable advantages for a sustainable recovery of MSO in Hong Kong. Throughout the last decades MSO has been overlooked by the government with a seriously lack of promotion, education and training and financial support. In practice shipping lines do decide about MSO. Nowadays they are tending increasingly towards container terminal services instead of MSO as container terminals provide a higher operational efficiency and safety level for people, vessel and cargo. In addition, there is some overcapacity at the Kwai Tsing container terminals which has led to a drastically decreased price gap between MSO and Kwai Tsing container terminals from $50 \%$ to $20 \%$. In addition the Kwai Tsing container terminals themselves are presently facing tough competition from nearby container ports like Yantian, Shekou and Nansha. Hong Kong port urgently needs to increase its attractiveness for all kind of containers. Thus, the government would be well advised to support the introduction of the PFB concept in Hong Kong in order to make MSO more attractive.

The only disadvantage of the PFB concept is its higher investment requirement which might refrains midstream operators from stepping into this advanced technology. This could be overcome by introducing drastically improved safety rules (to achieve a level playing field at international standards) which traditional HK barges are not able to comply with.

An advanced MSO concept would widen the scope of maritime services provided in Hong Kong and hence would strengthen the attractiveness of Hong Kong as an important regional container hub.

\section{Citation information}

Lau, Y.-Y., \& Malchow, U. (2019). Revising Hong Kong's midstream operation: A discussion on the Port Feeder Barge concept. Journal of Sustainable Development of Transport and Logistics, 4(2), 6-21. doi:10.14254/jsdtl.2019.4-2.1

\section{References}

Airriess, C. A. (2001). The regionalization of Hutchison port holdings in mainland China. Journal of Transport Geography, 9(4), 267-278. 
Asariotis, R., Benamara, H., Hoffmann, J., Núñez, E., Premti, A., \& Valentine, V. (2009). Review of Maritime Transport, 2009 (No. UNCTAD/RMT/2009).

Beyer, H., \& Pistol, B. (2009). Konzeptstudie zur Verlagerung vom Lkw auf Binnenschiffe und zur Stärkung der Hinterlandverkehre. Uniconsult GmbH, Hamburg, 14.

$\mathrm{Fu}, \mathrm{Q} ., \mathrm{Liu}, \mathrm{L.}$., \& Xu, Z. (2010). Port resources rationalization for better container barge services in Hong Kong. Marit. Pol. Mgmt., 37(6), 543-561.

Guoqiang, Z., Ning, Z., \& Qingyun, W. (2005). Container ports development and regional economic growth: An empirical research on the Pearl River Delta region of China. In Proceedings of the Eastern Asia Society for Transportation Studies (Vol. 5, pp. 2136-2150).

HKMOA. (2019). Hong Kong Mid-Stream Operators Association. Retrieved February 2018 from https://www.hkmoa.com

HKSAR LEGCO. (2004). Hong Kong Port - Master Plan 2020. Retrieved December 3, 2018 https://www.legco.gov.hk/yr04-05/english/panels/es/papers/es1122cb1-230-4e.pdf

Konings, R. (2004, November). Smart collection and distribution of containers on barge in the port of Rotterdam. In NECTAR cluster meeting (pp. 12-13).

Konings, R. (2007). Opportunities to improve container barge handling in the port of Rotterdam from a transport network perspective. Journal of Transport Geography, 15(6), 443-454.

Lau, Y. Y., \& Ng, A. K. (2017). An evaluation of mid-stream operation in Hong Kong. Maritime Business Review, 2(4), 410-422.

Lau, Y. Y., Ducruet, C., Ng, A. K., \& Fu, X. (2017). Across the waves: a bibliometric analysis of container shipping research since the 1960s. Maritime Policy \& Management, 44(6), 667-684.

Malchow, U. (2007). Port Feeder Barge - Intermodaler Anschluß für die Binnenschifffahrt (conferenceproceedings), 2, DVWG-Binnenschifffahrtsforum, Duisburg.

Malchow, U. (2010). StratMoS: Internal port traffic of containers, Study for the European Union, Hafen Hamburg Marketing e.V.

Malchow, U. (2012). Port Feeder Barge: Advanced Midstream Handling of Containers - optionally fuelled by LNG (conference proceedings), IFSPA, Hong Kong.

Malchow, U. (2018). A "Port Feeder Barge" fuelled by LNG for very green container logistics within seaports (conference proceedings), Green Port Conference, Valencia/Spain.

Marine Department. (2018). Retrieved November 28, 2018 from https://www.mardep.gov.hk.

Menist, M. (2008). Is transport congestion here to stay?. (conference proceedings), INTERMODAL 08, Hamburg.

Shippers Today. (1999). Midstream operations battle economic woes. Hong Kong Shippers' Council, Hong Kong.

The Government of Hong Kong (2018). Retrieved August 2018 from https://www.mardep.gov.hk.

Wang, J. J. (1998). A container load center with a developing hinterland: a case study of Hong Kong. Journal of Transport Geography, 6(3), 187-201.

Yeung, Y.M., Shen, J., \& Zhang, L. (2004). Hong Kong and the Western Pearl River Delta: cooperative Development from a Cross-Boundary Perspective. The Hong Kong Institute of Asia-Pacific Studies, The Chinese University of Hong Kong.

Ying Keung, P. W. (2009). The Future of Mid-Stream Operation in Hong Kong. VDM-Verlag, Saarbrücken.

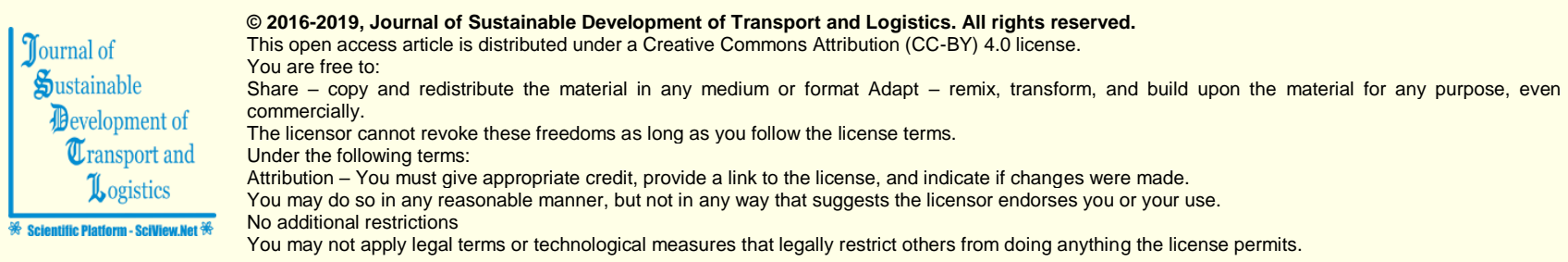

Journal of Sustainable Development of Transport and Logistics (ISSN: 2520-2979) is published by Scientific Publishing House "CSR", Poland, EU and Scientific Publishing House "SciView", Poland, EU

Publishing with JSDTL ensures:

.

. Immediate, universal access to your article on publication

- Rapid publication

Guaranteed legacy preservation of your article

Discounts and waivers for authors in developing regions

Submit your manuscript to a JSDTL at https://jsdtl.sciview.net/ or submit.jsdtl@sciview.net 